\title{
An Economic Theory of Fiduciary Law
}

\section{Citation}

Robert H. Sitkoff, An Economic Theory of Fiduciary Law in Philosophical Foundations of Fiduciary Law (Andrew Gold \& Paul Miller eds., 2014).

\section{Permanent link}

http://nrs.harvard.edu/urn-3:HUL.InstRepos:15274343

\section{Terms of Use}

This article was downloaded from Harvard University's DASH repository, and is made available under the terms and conditions applicable to Other Posted Material, as set forth at http:// nrs.harvard.edu/urn-3:HUL.InstRepos:dash.current.terms-of-use\#LAA

\section{Share Your Story}

The Harvard community has made this article openly available.

Please share how this access benefits you. Submit a story.

Accessibility 


\section{Philosophical Foundations of Fiduciary Law}

EDITED BY ANDREW S GOLD AND PAUL B MILLER 


\section{OXFORD \\ UNIVERSITY PRESS}

Great Clarendon Street, Oxford, OX2 6DP,

United Kingdom

Oxford University Press is a department of the University of Oxford. It furthers the University's objective of excellence in research, scholarship, and education by publishing worldwide. Oxford is a registered trade mark of

Oxford University Press in the UK and in certain other countries

(C) The several contributors 2014

The moral rights of the authors have been asserted

First Edition published in 2014

Impression: 1

All rights reserved. No part of this publication may be reproduced, stored in a retrieval system, or transmitted, in any form or by any means, without the prior permission in writing of Oxford University Press, or as expressly permitted by law, by licence or under terms agreed with the appropriate reprographics rights organization. Enquiries concerning reproduction outside the scope of the above should be sent to the Rights Department, Oxford University Press, at the address above

You must not circulate this work in any other form and you must impose this same condition on any acquirer

Crown copyright material is reproduced under Class Licence

Number C01P0000148 with the permission of OPSI and the Queen's Printer for Scotland

Published in the United States of America by Oxford University Press 198 Madison Avenue, New York, NY 10016, United States of America

British Library Cataloguing in Publication Data

$$
\text { Data available }
$$

Library of Congress Control Number: 2014934941

ISBN 978-0-19-870172-9

Printed and bound by

CPI Group (UK) Ltd, Croydon, CR0 4YY

Links to third party websites are provided by Oxford in good faith and for information only. Oxford disclaims any responsibility for the materials contained in any third party website referenced in this work. 


\title{
9 \\ An Economic Theory of Fiduciary Law
}

\author{
Robert H Sitkoff*
}

\section{Introduction}

Nearly two decades have passed since the publication of the seminal economic analyses of fiduciary law by Cooter and Freedman, ${ }^{1}$ and by Easterbrook and Fischel, ${ }^{2}$ which together have come to underpin the prevailing economic, contractarian model of fiduciary law. ${ }^{3}$ The principal-agent economic theory that motivates those papers has come to permeate the literature on law and legal institutions generally. ${ }^{4}$ The law-and-economics movement has matured further, developing new tools and refining its understanding of previously applied concepts. The purpose of this chapter is to restate the economic theory of fiduciary law, providing an updated and improved synthesis.

* This chapter is an expanded revision of Robert H Sitkoff, "The Economic Structure of Fiduciary Law," 91 BU L Rev 1039 (2011). In accordance with Harvard Law School's policy on conflicts of interest, the author discloses certain outside activities, one or more of which may relate to the subject matter of this chapter, at $<$ http://www.law.harvard.edu/faculty/COI/2013_Sitkoff_Robert.html>.

1 Robert Cooter and Bradley J Freedman, "The Fiduciary Relationship: Its Economic Character and Legal Consequences,” 66 NYU L Rev 1045 (1991).

2 Frank H Easterbrook and Daniel R Fischel, “Contract and Fiduciary Duty," 36 JL \& Econ 425 (1993).

3 In this context, the term contractarian is meant to reference economic contract theory, and the voluntary, agreement-based nature of a fiduciary relationship, not to suggest an identity between fiduciary and contract law.

There is, of course, a thick literature on fiduciarylaw. See, eg, Matthew Conaglen, Fiduciary Loyalty: Protecting the Due Performance of Non-Fiduciary Duties (2010); Tamar Frankel, Fiduciary Law (2011); Leonard I Rotman, Fiduciary Law (2005); Gregory S Alexander, "A Cognitive Theory of Fiduciary Relationships," 85 Cornell L Rev 767 (2000); Rob Atkinson, "Obedience as the Foundation of Fiduciary Duty," 34 J Corp L 43 (2008); Henry N Butler and Larry E Ribstein, "Opting out of Fiduciary Duties: A Response to the Anti-Contractarians," 65 Wash L Rev 1 (1990); Robert C Clark, "Agency Costs Versus Fiduciary Duties," in John W Pratt and Richard J Zeckhauser (eds), Principals and Agents: The Structure of Business (1985) 55; Deborah A DeMott, "Beyond Metaphor: An Analysis of Fiduciary Obligation," Duke LJ 879 (1988); Claire Moore Dickerson, "From Behind the Looking Glass: Good Faith, Fiduciary Duty \& Permitted Harm," 22 Fla St U L Rev 955 (1995); James Edelman, "When Do Fiduciary Duties Arise?," 126 LQ Rev 302 (2010); Scott FitzGibbon, "Fiduciary Relationships Are Not Contracts," 82 Marq L Rev 303 (1999); Robert Flannigan, "The Economics of Fiduciary Accountability," 32 Del J Corp L 393 (2007); Tamar Frankel, "Fiduciary Duties as Default Rules," 74 Or L Rev 1209 (1995); Arthur B Laby, "The Fiduciary Obligation as the Adoption of Ends," 56 Buff L Rev 99 (2008); Melanie B Leslie, "Trusting Trustees: Fiduciary Duties and the Limits of Default Rules", 94 Geo LJ 67 (2005); Paul B Miller, "Justifying Fiduciary Duties," 58 McGill LJ 969 (2013); Paul B Miller, "A Theory of Fiduciary Liability," 56 McGill LJ 235 (2011); R C Nolan, “Controlling Fiduciary Power," 68 Cambridge LJ 293 (2009); L S Sealy, "Fiduciary Relationships," Cambridge LJ 69 (1962); J C Shepherd, “Towards a Unified Concept of Fiduciary Relationships,” 97 LQ Rev 51 (1981); D Gordon Smith, “The Critical Resource Theory of Fiduciary Duty," 55 Vand L Rev 1399 (2002); Ernest J Weinrib, “The Fiduciary Obligation,” 25 U Toronto LJ 1 (1975).

${ }^{4}$ For example, I have elsewhere developed an agency theory of trust law. See Robert H Sitkoff, "An Agency Costs Theory of Trust Law," 89 Cornell L Rev 621 (2004); see also Jonathan Klick and Robert H Sitkoff, "Agency Costs, Charitable Trusts, and Corporate Control: Evidence from Hershey's Kiss-Off," 108 Colum L Rev 749, 779-83 (2008); Robert H Sitkoff, “Trust Law as Fiduciary Governance Plus Asset Partitioning," in Lionel Smith (ed), The Worlds of the Trust (2013) 428. 
In restating the economic theory of fiduciary law, this chapter makes three fresh contributions. First, it elaborates on earlier work by clarifying the agency problem that is at the core of all fiduciary relationships. In consequence of this common economic structure, there is a common doctrinal structure that cuts across the application of fiduciary principles in different contexts. However, within this common structure, the particulars of fiduciary obligation vary in accordance with the particulars of the agency problem in the fiduciary relationship at issue. This point explains the purported elusiveness of fiduciary doctrine. It also explains why courts apply fiduciary law both categorically, such as to trustees and (legal) agents, as well as ad hoc, to relationships involving a position of trust and confidence that give rise to an agency problem.

Second, this chapter identifies a functional distinction between primary and subsidiary fiduciary rules. In all fiduciary relationships we find general duties of loyalty and care, typically phrased as standards, which proscribe conflicts of interest and prescribe an objective standard of care. But we also find specific subsidiary fiduciary duties, often phrased as rules, that elaborate on the application of the duties of loyalty and care to commonly recurring circumstances in the particular form of fiduciary relationship. Together, the general primary duties of loyalty and care and the specific subsidiary rules provide for governance by a mix of rules and standards that offers the benefits of both while mitigating their respective weaknesses.

Third, this chapter revisits the puzzle of why fiduciary law includes mandatory rules that cannot be waived in a relationship deemed fiduciary. Committed economic contractarians, such as Easterbrook and Fischel, have had difficulty in explaining why the parties to a fiduciary relationship do not have complete freedom of contract. ${ }^{5}$ The answer is that the mandatory core of fiduciary law serves a cautionary and protective function within the fiduciary relationship as well as an external categorization function that clarifies rights for third parties. The existence of a mandatory fiduciary core is thus reconcilable with an economic theory of fiduciary law.

The remainder of this chapter is organized as follows. Section I examines the agency problem that is the common economic structure at the core of fiduciary relationships. Section II examines the fiduciary governance strategy for containing agency costs in such relationships. Section III examines the mandatory core of fiduciary law that has embarrassed prior economic analyses. Section IV examines the remedial structure of fiduciary law, focusing on compensatory and disgorgement remedies. A short conclusion follows.

\section{The Agency Problem}

The law tends to impose fiduciary obligation in circumstances that present what economists call a principal-agent or agency problem. An agency problem arises whenever one person, the principal, engages another person, the agent, to undertake imperfectly observable discretionary actions that affect the welfare of the principal. ${ }^{6}$ Agency

\footnotetext{
5 See text accompanying $n 42$.

${ }^{6}$ See Michael C Jensen and William H Meckling, "Theory of the Firm: Managerial Behavior, Agency Costs and Ownership Structure," 3 J Fin Econ 305, 308 (1976).
} 
problems therefore arise not only in relationships governed by the common law of agency, but also in trust law, corporate law, and a host of other contexts.

Agency problems are pervasive because no one has the skills necessary to do everything for himself and because every undertaking has an opportunity cost. By delegating a task to an agent, the principal benefits from specialist service and is freed to undertake some other activity. But these benefits come at the cost of being made vulnerable to abuse if the agent is given discretion the exercise of which cannot easily be observed or verified. In such circumstances, the agent may be tempted to favor the agent's interests when they diverge from those of the principal. The losses and other inefficiencies resulting from this misalignment of interests are called agency costs. ${ }^{7}$

Removing or limiting the agent's discretion is not a satisfactory answer to an agency problem. Often the principal cannot spell out in advance precisely what the agent should do in all possible future circumstances. This problem of incomplete contracting arises from transaction costs - the impossibility of anticipating all future contingencies and the infeasibility of reducing to writing instructions for every contingency that can be anticipated. Moreover, in many circumstances the very purpose of retaining an agent with expertise is undermined if the agent is not given room to apply that expertise on behalf of the principal to changing conditions. Disempowering the agent protects the principal from mis- or malfeasance, but it also disables the agent from undertaking acts useful for the principal.

Active monitoring is likewise not a satisfactory answer to an agency problem. Even if the principal has spelled out what the agent should do in a particular contingency, the principal may not be able to monitor the agent's compliance with those instructions. Agents often are retained because the principal lacks the specialized skills necessary to undertake the activity without assistance. In such a case, the skill deficit that prompted the principal to engage the agent renders the principal vulnerable to abuse by limiting the principal's ability to monitor the agent.

To the extent that circumstances outside of the agent's control may affect the outcome, judging the agent on the basis of the agent's results is an imperfect solution to an agency problem. Suppose a real estate agent cannot locate a suitable buyer for a home at a homeowner's desired price. The homeowner can seldom ascertain whether the agent's failure reflects the agent's inadequate effort, the homeowner's overpricing, or a slumping market. The homeowner's inability to assess the cause of the agent's failure is a form of post-contractual information asymmetry known as hidden action or moral hazard. ${ }^{8}$

Another possibility for ameliorating the agency problem is incentive-based compensation. A real estate agent is typically compensated by a percentage of the sale price to give the agent a financial incentive to maximize that price. But no compensation agreement short of selling the house to the agent will completely remove the possibility of divergence of interest and with it the temptation for the agent to favor the agent's own interests. Consider a real estate agent working on a 5 percent commission. Such an agent will have no incentive to undertake $\$ 100$ of additional effort to increase the sale

\footnotetext{
7 See Jensen and Meckling (n 6) at 308.

8 See, eg, Jean-Jacques Laffont and David Martimort, The Theory of Incentives: The Principal-Agent Model (2002) 3 .
} 
price by $\$ 1,000$, because the payoff to the agent of doing so is only $\$ 50$ (5 percent of $\$ 1,000) .{ }^{9}$ By contrast, if the agent owned the home he would undertake the additional $\$ 100$ in effort for the $\$ 1,000$ increase in the sale price. But solving the incentive problem by selling the house to the agent-in effect, removing the agency-is often impractical. The typical real estate agent could not bear the risk of buying his clients' homes for resale (a risk-sharing problem ${ }^{10}$ ), and his clients would still be dependent on his faithfulness in pricing the home (a hidden information or adverse selection problem ${ }^{11}$ ).

In summary, the difficult task for legal institutional design is to "protect[] the principal from the vulnerability that any relationship of agency creates by exposing the principal's property or interests more generally to the risk of self-interested action by the agent." ${ }^{12}$ The task, in other words, is to design a body of law applicable to agency relationships that minimizes agency costs while preserving the benefits of agency.

\section{The Fiduciary Governance Strategy}

\section{A. Categorical and ad hoc deterrence}

Agency problems are the defining hallmark of categorical fiduciary relationships, such as those between trustee and beneficiary, guardian and ward, principal and agent (in law), director and corporation, and lawyer and client. If you are a trustee, a guardian, an agent, a director, or a lawyer, you almost certainly have the kind of difficult-to-observe discretionary power affecting the principal's welfare that gives rise to an agency problem. In consequence, as a categorical matter you are a fiduciary, subject to fiduciary duties, and your discretionary powers are held in a fiduciary capacity. The Restatement (Third) of Trusts calls this "a basic principle of trust administration," namely, that "a trustee presumptively has comprehensive powers to manage the trust estate and otherwise to carry out the terms and purpose of the trust, but that all powers held in the capacity of trustee must be exercised, or not exercised, in accordance with the trustee's fiduciary obligations." ${ }^{13}$

But the categorical fiduciary relationships do not exhaust the universe of potential agency problems. An agency problem may arise in other relationships, depending on the circumstances. Accordingly, courts impose fiduciary duties ad hoc in relationships of "trust and confidence" that present an agency problem but that are not categorically fiduciary. ${ }^{14}$ Burdett $v$ Miller, ${ }^{15}$ an opinion by Judge Posner, is illustrative. Noting that

\footnotetext{
9 This example derives from Frank H Easterbrook and Daniel R Fischel, The Economic Structure of Corporate Law (1991) 91.

${ }^{10}$ Agency relationships, in other words, present both incentive and risk-sharing problems. See, eg, Cooter and Freedman (n 1) at 1068; Kathleen M Eisenhardt, "Agency Theory: An Assessment and Review," 14 Acad Mgmt Rev 57, 58 (1989).

11 See, eg, Laffont and Martimort (n 8) at 3.

12 Restatement (Third) of Agency (2006) $\$ 8.01 \mathrm{cmt}$ b. Although the quoted provision refers to common law agency, the point pertains to all agency relationships using that term in an economic rather than legal sense.

13 Restatement (Third) of Trusts (2007) $\$ 70 \mathrm{cmt}$ a.

14 See, eg, Wiener v Lazard Freres \& Co 672 NYS2d 8, 14 (App Div 1998) (noting that fiduciary obligation may arise if "a party reposed confidence in another and reasonably relied on the other's superior expertise or knowledge"); Restatement (Third) of Agency $\$ 8.01 \mathrm{cmt} c$ (noting imposition of fiduciary obligation "on the basis that one party to the relationship has in fact reposed trust and confidence in the other and has done so consistently with the other's invitation").

15957 F2d 1375 (7th Cir 1992).
} 
"the relation between an investment advisor and the people he advises is not" a per se fiduciary category, the court imposed fiduciary duties on the defendant investment adviser nonetheless. ${ }^{16}$ The plaintiff had "reposed trust and confidence" in the defendant, who had held himself out "to be expert as well as trustworthy." ${ }^{7}$ The defendant had gained "influence and superiority over" the plaintiff by virtue of his claimed "expert knowledge the deployment of which the [plaintiff could not] monitor." ${ }^{8}$

In both fiduciary applications, categorical and ad hoc, imposition of fiduciary obligation is meant to ameliorate the underlying agency problem. Under the fiduciary governance strategy, an agent who has broad discretionary power may act in the moment, but afterwards the principal is invited to scrutinize whether the agent's action was indeed in the principal's best interests. Stripped of legalistic formalisms and moralizing rhetoric, ${ }^{19}$ the functional core of fiduciary obligation is deterrence. ${ }^{20}$ The agent is induced to act in the best interests of the principal by the threat of after-the-fact liability for failure to have done so. Deterrence in this sense means ex post settling up with the principal for any breach of the agent's ex ante fiduciary duties.

\section{B. Loyalty and care}

The primary fiduciary duties are loyalty and care. The duty of loyalty proscribes misappropriation and regulates conflicts of interest by requiring a fiduciary to act in the "best" or even "sole" interests of the principal. The fiduciary may obtain the principal's consent to a conflict, but only in accordance with certain procedural and substantive safeguards, chief among them full and fair disclosure by the fiduciary. ${ }^{21}$ The aim is to induce the fiduciary to avoid the conflict or to disclose the material facts of how the conflict might compromise the fiduciary's judgment, thereby enabling the principal to make an informed decision whether to consent to the conflict. ${ }^{22}$ In concert with the availability of a disgorgement remedy for breach, the prophylactic ban on self-dealing by a fiduciary thus serves a disclosure or revelatory purpose. ${ }^{23}$

\footnotetext{
16957 F2d 1375 (n 15) at $1381 . \quad{ }^{17} 957$ F2d 1375 (n 15) at 1381.

18957 F2d 1375 (n 15) at 1381. See also Patsos v First Albany Corp 741 NE2d 841, 849-50 (Mass 2001) (applying fiduciary duties ad hoc to an investment adviser).

19 The most famous such rhetoric is that of Justice Cardozo in Meinhard $v$ Salmon:

Many forms of conduct permissible in a workaday world for those acting at arm's length, are forbidden to those bound by fiduciary ties. A trustee is held to something stricter than the morals of the market place. Not honesty alone, but the punctilio of an honor the most sensitive, is then the standard of behavior. As to this there has developed a tradition that is unbending and inveterate. Uncompromising rigidity has been the attitude of courts of equity when petitioned to undermine the rule of undivided loyalty by the "disintegrating erosion" of particular exceptions. Only thus has the level of conduct for fiduciaries been kept at a level higher than that trodden by the crowd. It will not consciously be lowered by any judgment of this court.

164 NE 545, 546 (NY 1928) (citation omitted).

${ }^{20}$ See Frank H Easterbook and Daniel R Fischel, “Corporate Control Transactions," 91 Yale LJ 698, 702 (1982).

${ }^{21}$ See, eg, Restatement (Third) of Trusts $\$ 78 \mathrm{cmts} c$, d; Restatement (Third) of Agency $\$ \$ 8.01-8.06$;

Principles of Corporate Governance: Analysis and Recommendations (1994) $\$ \$ 5.01-5.02$.

22 See, eg, Restatement (Third) of Agency $\$ 8.06 \mathrm{cmt}$ b.

${ }^{23}$ See text accompanying n 55 .
} 
The duty of care prescribes the fiduciary's standard of care by establishing a "reasonableness" or "prudence" standard that is informed by industry norms and practices. The fiduciary standard of care is objective, measured by reference to a reasonable or prudent person in like circumstances. ${ }^{24}$ If a fiduciary has specialized skills relevant to the principal's retention of the fiduciary, then the applicable standard of care is that of a reasonable or prudent person in possession of those skills. ${ }^{25}$

Because agency problems arise from incomplete contracting, the core duties of loyalty and care are phrased in general terms. The duties of loyalty and care are standards that allow the court to decide whether, in view of all the circumstances, the fiduciary acted in accord with what the parties would have agreed if they had been able to anticipate those circumstances. In effect, the loyalty and care standards empower the court to complete the parties' contract after the fact. Fiduciary law thus minimizes transaction costs. Instead of trying in advance to reduce to writing provisions for every future contingency, the parties need only specify those contingencies that are important and likely enough to warrant the transaction costs of express provision. For all other contingencies, fiduciary obligation fills the gap.

As standards that allow for consideration of all relevant circumstances, the duties of loyalty and care minimize error costs. But as is typical of standards (as compared to rules), this reduction in error costs comes at the price of increased uncertainty and decision costs. ${ }^{26}$ The highly contextual nature of a standard makes prediction more difficult and requires a more intensive judicial role.

However, the normal accretive process of common law development has ameliorated this problem by producing a rich body of interpretive authority on fiduciary matters. This mass of authority improves predictability by providing instructive guidance on how the duties of loyalty and care will be applied in various circumstances. It also addresses the extent to which the parties may override fiduciary duties by explicit agreement and the remedies available upon breach of duty. ${ }^{27}$

\section{Subsidiary or implementing rules}

The uncertainty arising from the nature of the duties of loyalty and care as standards is further mitigated by the development of specific subsidiary or implementing rules that elaborate on the application of loyalty and care to recurring circumstances. This point is perhaps best explained by way of illustration.

Within trust law, the duty of care (called prudence in trust parlance) is elaborated in application to the investment function by the prudent investor rule. ${ }^{28}$ With regard to the custodial and administrative functions, the duties of loyalty and prudence are

\footnotetext{
${ }^{24}$ See, eg, Restatement (Third) of Trusts $\$ 77$; Restatement (Third) of Agency $\$ 8.08$; Principles of Corporate Governance: Analysis and Recommendations $\$ 4.01(\mathrm{a})$.

${ }^{25}$ See, eg, Unif Prudent Investor Act $\$ 2$ (f) (1994); Restatement (Third) of Trusts $\$ 77(3)$; Restatement (Third) of Agency $₫ 8.08$.

${ }^{26}$ See, eg, Louis Kaplow, “Rules Versus Standards: An Economic Analysis," 42 Duke LJ 557 (1992).

27 See Sections III-IV.

${ }^{28}$ See, eg, John H Langbein, "The Uniform Prudent Investor Act and the Future of Trust Investing," 81 Iowa L Rev 641 (1996); Max M Schanzenbach and Robert H Sitkoff, "Did Reform of Prudent Trust Investment Laws Change Trust Portfolio Allocation?", 50 JL \& Econ 681 (2007).
} 
elaborated by subsidiary duties to collect, protect, earmark, and not commingle trust property; to keep adequate records of administration; and to bring and defend claims. ${ }^{29}$ The duty of impartiality and the principal and income rules elaborate on loyalty and prudence in trusts with multiple beneficiaries with divergent interests. ${ }^{30}$ Still another subsidiary rule requires advance disclosure to the beneficiaries of significant developments or non-routine transactions in the administration of the trust. ${ }^{31}$

In agency law, the duty of loyalty is elaborated by more specific duties pertaining to conflicted transactions, competition with the principal, and protection of confidences. ${ }^{32}$ In corporate law, the corporate opportunities doctrine elaborates on the application of loyalty to the recurring circumstance of the temptation for a director or officer to usurp a business opportunity that could have been beneficial for the corporation. ${ }^{33}$

The subsidiary rules simplify application of fiduciary obligation to cases that fall within their terms, reducing decision costs. ${ }^{34}$ One need not show that the duty of care requires accurate record keeping, for example, if one can invoke a subsidiary rule that imposes such a duty. Moreover, the subsidiary rules offer the typical benefit of simple rules, reduced decision costs, without increasing error costs by providing a roadmap for strategic avoidance behavior. If a fiduciary acts in a manner that is inimical to the principal's interests but that does not fall within one or another subsidiary rule, the principal may invoke the standards of loyalty and care. Operating in tandem, the general primary duties of loyalty and care plus the specific subsidiary rules provide the decision costs advantage of rules and the error costs advantage of standards. ${ }^{35}$

\section{Common structure with varied particulars}

Because fiduciary law provides for an after-the-fact compliance review of the fiduciary's conduct, and because the nature of the underlying agency problem varies across fiduciary relationships, the precise contours of fiduciary obligation vary across fields. For example, the fiduciary obligation in trust law is generally stricter than in corporate law. But those differences reflect the different contexts. The agency problem in a family trust in which the beneficiaries have no exit option and that is managed by a corporate fiduciary that cannot easily be replaced differs significantly from the agency problem in a publicly traded corporation from which a shareholder can separate easily by selling his shares in a thick securities market. ${ }^{36}$

\footnotetext{
29 See Jesse Dukeminier and Robert H Sitkoff, Wills, Trusts, and Estates (9th edn, 2013) 646-9.

${ }^{30}$ See Dukeminier and Sitkoff (n 29) at 657-67.

${ }^{31}$ See Restatement (Third) of Trusts $\$ 82 \mathrm{cmt} \mathrm{d}$.

32 See Restatement (Third) of Agency $\$ \$ 8.01-8.06$.

${ }^{33}$ See Stephen M Bainbridge, Corporate Law (2nd edn, 2009) $\$ 7.3$.

${ }^{34}$ See Sitkoff, "An Agency Costs Theory of Trust Law" (n 4) at 682-3.

${ }^{35}$ I have elsewhere characterized this mode of governance as a "standard tempered by presumptions," in comparison to a "rule tempered by exceptions." Dukeminier and Sitkoff (n 29) at 379-80. The dynamic in fiduciary law thus stands apart from the conventional story in property law. As opportunists find a new trick, the "mud" of loyalty and care becomes a "crystal" of a subsidiary rule addressing that trick. Cf Carol M Rose, “Crystals and Mud in Property Law" 40 Stan L Rev 577 (1988).

${ }^{36}$ See Robert H Sitkoff, “Trust Law, Corporate Law, and Capital Market Efficiency," 28 J Corp Law 565 (2003); see also Stephen M Bainbridge, “The Case for Limited Shareholder Voting Rights”, 53 UCLA L Rev 601, 619 (2006).
} 
Likewise, the subsidiary fiduciary rules differ across fiduciary applications in accordance with variations in the underlying agency problems. Because a trust is a fiduciary relationship with respect to property, many trust fiduciary subrules address property management. Because the paradigmatic (legal) agent acts on behalf of the principal in a commercial undertaking, many agency fiduciary subrules concern competition with the principal and protection of confidences.

Accordingly, what has been called the elusiveness of fiduciary law is more properly regarded as context-specific adaptation. The flexibility of fiduciary obligation explains the success of the fiduciary governance strategy. Across the decades, courts and legislatures have adapted the general duties of loyalty and care and have created specific subsidiary duties to fit the particulars of the agency problem at issue.

\section{Mandatory and Default Rules}

Generally speaking, fiduciary duties yield to a contrary agreement of the parties. This principle follows from the nature of fiduciary governance as a system of deterrence meant to minimize agency costs by allowing the court to complete the parties' contract after the fact. The requirement that a fiduciary act in the principal's best interests, which is informed by what the parties would have agreed if they had considered a given contingency, does not pertain if the parties entered into an express agreement on what the fiduciary should do in the event of a particular contingency. Fiduciary law consists mostly of default rules that apply unless the parties have agreed otherwise.

Even the duty of loyalty is subject to modification by agreement of the parties. ${ }^{37}$ If the principal gives informed consent to certain self-dealing by the fiduciary, the rationale for the rule against self-dealing falls away. In such circumstances, the fiduciary may engage in the specified self-dealing, provided that the fiduciary acts in good faith and that the transaction is objectively fair and in the best interests of the principal. ${ }^{38}$

As is implied by the good faith, fairness, and best interests qualifiers, there are nonetheless some mandatory rules in fiduciary law that cannot be overridden by agreement. It is well settled within trust law, for example, that "no matter how broad the provisions of a trust may be in conferring power to engage in self-dealing or other transactions involving a conflict of fiduciary and personal interests, a trustee violates the duty of loyalty to the beneficiaries by acting in bad faith or unfairly." 39 A trustee may be exonerated, but not "for a breach of trust committed in bad faith or with indifference to the fiduciary duties of the trustee, the terms or purposes of the trust, or the interests of the beneficiaries." 40

Stated more broadly, if a principal authorizes self-dealing by a fiduciary, fiduciary law imposes substantive and procedural safeguards. The fiduciary must act in good

\footnotetext{
37 See, eg, Unif Power of Attorney Act $\$ 114(\mathrm{~b})$ (2006); Restatement (Third) of Trusts $\$ 78 \mathrm{cmt} c(2)$; Restatement (Third) of Agency $\$ 8.06$.

${ }^{38}$ See, eg, Restatement (Third) of Trusts $\$ 78 \mathrm{cmts} \mathrm{c,d;} \mathrm{Restatement} \mathrm{(Third)} \mathrm{of} \mathrm{Agency} \$$ 8.06; Principles of Corporate Governance: Analysis and Recommendations $\$ 5.02$.

${ }^{39}$ Restatement (Third) of Trusts $\$ 78 \mathrm{cmt} \mathrm{c}(2)$; see also Unif Power of Attorney Act $\$ 114(\mathrm{a})$; Unif Trust Code $\$ 105(\mathrm{~b})(2)$ (amended 2005); Restatement (Third) of Agency $\$ 8.06(1)(\mathrm{a}),(2)(\mathrm{a})$.

${ }^{40}$ Restatement (Third) of Trusts $\$ 96(1)(a)$; see also Unif Trust Code $\$ 1008(2000)$.
} 
faith and deal fairly with and for the principal, and the fiduciary must apprise the principal of the material facts, the facts that would reasonably affect the principal's judgment, in securing the principal's informed consent. ${ }^{41}$

The existence of a mandatory core of fiduciary law vexed the prior generation of economic analysis. Committed contractarians have had difficulty in explaining why the parties to a fiduciary relationship do not have complete freedom of contract. Easterbrook and Fischel went so far as to assert, erroneously, that in trust law "[a]ll rules are freely variable by contract in advance." ${ }^{2}$ The answer is not to deny the existence of mandatory fiduciary rules, but rather to see that they serve an internal protective and cautionary function that protects the principal, and an external categorization function that protects third parties and clarifies the nature of the parties' relationship.

With respect to the internal protective and cautionary function, the mandatory core insulates fiduciary obligations that the law assumes would not be bargained away by a fully informed, sophisticated principal. True, in an individual case a particular principal might be fully informed and have good reason to want to bargain away something from the mandatory core. But such circumstances are infrequent enough that a prophylactic (if paternalistic) mandatory rule may be justified nonetheless, at least in the traditional fiduciary fields such as trust and agency, in which the principal is commonly not sophisticated and fully informed.

With respect to the external categorization function, the mandatory core addresses the need for clean lines of demarcation across types of legal relationships, among other things to minimize third-party information costs. ${ }^{43}$ On this view, fiduciary obligation is a necessary constitutive element of certain legal categories, such as trust and agency. Thus, in the Restatement (Third) of Agency, we find the remark that "[a] relationship between two parties in which it is agreed that one party shall have the right to take action that affects the legal relations of the other party without regard for whether the action is for that party's benefit is not a relationship of [legal] agency." ${ }^{\prime 4}$ Likewise, in the Restatement (Third) of Trusts, we find the statement that "there are limits to the settlor's freedom" to waive fiduciary obligation, "thereby protecting the fundamental fiduciary character of trust relationships recognized by the law." ${ }^{35}$

So the mandatory core of fiduciary law polices the line that differentiates a fiduciary relationship on the one hand from a fee simple or other such arrangement on the other. A person may give property to another person and authorize the other person to act whimsically with respect to the property. But this mode of transfer is an absolute gift, and this mode of holding property is fee simple. Perhaps the leading statement of this

\footnotetext{
${ }^{41}$ See, eg, Unif Trust Code $\$ 1009$ (amended 2001); Restatement (Third) of Trusts $\$ 78 \mathrm{cmt} c(2)$; Restatement (Third) of Agency $\$ 8.06$.

${ }^{42}$ Easterbrook and Fischel (n 2) at 432.

43 This standardization function has been emphasized in the contemporary learning in property theory. See, eg, Henry Hansmann and Reinier Kraakman, "Property, Contract, and Verification: The Numerus Clausus Problem and the Divisibility of Rights," 31 J Legal Stud S373 (2002); Thomas W Merrill and Henry E Smith, "The Property/Contract Interface," 101 Colum L Rev 773 (2001); Thomas W Merrill and Henry E Smith, "Optimal Standardization in the Law of Property: The Numerus Clausus Principle," 110 Yale LJ 1 (2000); see also Sitkoff, "An Agency Costs Theory of Trust Law" (n 4) at 643.

${ }^{44}$ Restatement (Third) of Agency $\$ 8.06 \mathrm{cmt}$ b. $\quad{ }^{45}$ Restatement (Third) of Trusts $\$ 78 \mathrm{cmt} c(2)$.
} 
point in the American cases is by the Supreme Court of Delaware in McNeil v McNeil. ${ }^{46}$ At issue in that case was a clause in a trust instrument stating that the trustees' decisions were "not subject to review by any court." ${ }^{47}$ Observing that courts "flatly refuse to enforce provisions relieving a trustee of all liability," the court reviewed the trustees' action nonetheless. ${ }^{48}$ The reason: "A trust in which there is no legally binding obligation on a trustee is a trust in name only and more in the nature of an absolute estate or fee simple grant of property." ${ }^{49}$

The categorization explanation for the mandatory core is strongest as regards fiduciary relationships for which there is no public notice filing, such as agency and common law trusts. The explanation is weaker as regards filing entities, such as corporations and limited liability companies, because the public filing that brings the entity into existence also provides notice of the existence and nature of the entity. For this reason, and because the parties in such contexts are more likely to be fully informed and sophisticated, the mandatory core for filing fiduciary entities is both less robust and more contentious than in agency and trust law. ${ }^{50}$ Consistent with this analysis, we find in the recent uniform acts in the fiduciary fields a consolidated scheduling of mandatory rules, but with more flexibility in the filing fiduciary entities than in the non-filing fiduciary relationships. ${ }^{51}$

\section{Compensation and Disgorgement}

In the event of a fiduciary's breach of duty, the principal is entitled to an election among remedies that include compensatory damages to offset any losses incurred or to make up any gains forgone owing to the fiduciary's breach, or to disgorgement by the fiduciary of any profit accruing to the fiduciary by reason of the breach. ${ }^{52}$ The former is a standard measure of make-whole compensatory damages. The latter is a restitutionary

\footnotetext{
${ }^{46}$ McNeil v McNeil 798 A2d 503 (Del 2002).

${ }^{47}$ McNeil v McNeil (n 46) at 509.

${ }_{48}$ McNeil v McNeil (n 46) at 509.

$49 M c N e i l v M c N e i l$ ( $\mathrm{n} 46$ ) at 509. A few years earlier, in Armitage $v$ Nurse, Lord Justice Millet applied the same principle to an English trust: "[T]here is an irreducible core of obligations owed by the trustees to the beneficiaries and enforceable by them which is fundamental to the concept of a trust. If the beneficiaries have no rights enforceable against the trustees there are no trusts." [1998] Ch 241 at 253 (CA 1997) (Eng).

50 See, eg, Gatz Props, LLC v Auriga Capital Corp 59 A3d 1206, 1218-20 (Del 2012) (remarking that "the issue whether the LLC statute does-or does not-impose default fiduciary duties is one about which reasonable minds could differ"); Larry E Ribstein, The Rise of the Uncorporation (2010) 219-22; Andrew S Gold, "On the Elimination of Fiduciary Duties: A Theory of Good Faith for Unincorporated Firms," 41 Wake Forest L Rev 123 (2006). Recent legislation in Delaware clarifies that fiduciary law applies to unincorporated entities. Del Code Ann tit 6, \$ 18-1104 (2013) (Limited Liability Company Act); Del Code Ann tit 6, § 17-1105 (Delaware Revised Uniform Limited Partnership Act).

${ }^{51}$ Compare Unif Statutory Trust Entity Act $\$ 104$ (2009), and Revised Unif Limited Liability Company Act $\$ 110$ (2006), and Unif Limited Partnership Act $\$ 110$ (2001), and Revised Unif Partnership Act $\$ 103$ (1997), and Unif Limited Liability Company Act $\$ 103$ (1996), and Mark J Loewenstein, "Fiduciary Duties and Unincorporated Business Entities: In Defense of the 'Manifestly Unreasonable' Standard," 41 Tulsa L Rev 411 (2006) (discussing mandatory rules in the uniform alternative entity acts), with Unif Power of Attorney Act $\$ 114$ (2006), and Unif Trust Code $\$ 105$ (amended 2005), and John H Langbein, "Mandatory Rules in the Law of Trusts," 98 Nw U L Rev 1105 (2004) (discussing mandatory rules in the Uniform Trust Code).

${ }^{52}$ See, eg, Unif Trust Code $\$$ 1002(a) (2000); Austin Wakeman Scott, William Franklin Fratcher, and Mark L Ascher, Scott and Ascher on Trusts (4th edn, 2007) \$24.9.
} 
remedy that, within the American tradition, is commonly implemented by way of a constructive trust to prevent unjust enrichment of the breaching fiduciary. ${ }^{53}$

The availability of a compensatory remedy is readily explainable on ordinary contractarian terms. The principal is entitled to the benefit of his bargain, hence to be made whole for his losses incurred or gains forgone owing to the breach. But compensatory damages will deter breach only if the gains from breach to the fiduciary are less than the principal's loss or gains forgone. If only compensatory damages are available, and the gains to the fiduciary from breach exceed the compensatory damages that will be due to the principal, then, for the fiduciary, breach will be efficient. ${ }^{54}$ The fiduciary will have no incentive to refrain from breach and return to the principal to negotiate over allocation of the surplus.

The availability of a disgorgement remedy, which allows the principal to take the breaching fiduciary's gain even in excess of making the principal whole, reflects the additional disclosure and deterrence purposes of fiduciary law. ${ }^{55}$ Because the fiduciary is not entitled to keep any gains resulting from breach, he is given an incentive to disclose the potential for such gains and to work out with the principal how much of the surplus will go to each party. Put in more formal doctrinal terms, the default rule in fiduciary law is that all gains that arise in connection with a fiduciary relationship belong to the principal unless the parties specifically agree otherwise. This rule, which is contrary to the preferences of the party with superior information, the fiduciary, offers deterrence in the penalty default sense. ${ }^{56}$ On this view, the disgorgement remedy is a penalty default rule that induces disclosure.

But what about a cunning fiduciary who reckons that the principal may not be able to discover the fiduciary's secret profits? The recognition in modern law of punitive damages for such egregious fiduciary breaches is a sign of movement toward deterrence of such cases. ${ }^{57}$ The Restatement (Third) of Trusts, for example, recognizes the need "to deter similar misconduct" as a basis for awarding punitive damages. ${ }^{58}$

\section{Conclusion}

In contrast to an arms-length relationship, in which each party is free to be self-serving, in a fiduciary relationship the law requires the fiduciary to be other-regarding because of the potential for abuse inherent to the agency structure of the relationship. What is meant by other-regarding is defined by general primary fiduciary duties of loyalty and care and a host of specific subsidiary fiduciary duties. Fiduciary duties are subject to refinement by agreement of the parties, so long as the fiduciary remains obligated to act

\footnotetext{
${ }^{53}$ See Restatement (Third) of Restitution \& Unjust Enrichment (2011) $\$ 55$. For criticism of the American tradition, see Lionel Smith, "Legal Epistemology in the Restatement (Third) of Restitution and Unjust Enrichment," 92 BU L Rev 899, 907-16 (2012).

54 See, eg, Richard A Posner, Economic Analysis of Law (8th edn, 2011) \$4.10.

55 See nn 21-2 and accompanying text.

56 See Ian Ayres and Robert Gertner, "Filling Gaps in Incomplete Contracts: An Economic Theory of Default Rules," 99 Yale LJ 87 (1989).

57 See Restatement (Third) of Trusts (2012) $\$ 100 \mathrm{cmt}$ d; A Mitchell Polinsky and Steven Shavell, "Punitive Damages: An Economic Analysis," 111 Harv L Rev 869 (1998).

${ }^{58}$ Restatement (Third) of Trusts $\$ 100 \mathrm{cmt}$ d.
} 
in good faith and in the best interests of the principal. Agency theory, and in particular its emphasis on the problem of opportunism in circumstances of asymmetric information, explains these basic contours of fiduciary doctrine.

In restating the economic theory of fiduciary law, this chapter made three fresh contributions. First, it expanded on earlier work by clarifying the agency problem that is at the core of all fiduciary relationships. The fact of this common economic structure explains the common doctrinal structure that cuts across fiduciary relationships. But the particulars of fiduciary obligation vary across fiduciary relationships in accordance with the particulars of the agency problem at issue. In addition to explaining the purported elusiveness of fiduciary law, this point also explains why courts apply fiduciary law both categorically, such as in trust, agency, and corporate law, as well as ad hoc to relationships involving trust and confidence giving rise to an agency problem.

Second, this chapter identified a functional distinction between primary and subsidiary fiduciary duties. Across fiduciary relationships we find general primary duties of loyalty and care, typically phrased as standards, which proscribe conflicts of interest and prescribe an objective standard of care. We also find specific subsidiary fiduciary rules that elaborate on the application of the duties of loyalty and care to recurring circumstances within the particular type of fiduciary relationship. Together, the general primary duties of loyalty and care and the specific subsidiary rules provide for governance by a mix of rules and standards that offers the benefits of both while mitigating their respective weaknesses.

Third, this chapter revisited the puzzle of why fiduciary law includes a mandatory core that cannot be waived by the parties if they are in a relationship that is deemed to be fiduciary. The answer is that the mandatory core serves a cautionary and protective function within the fiduciary relationship as well as an external categorization function that clarifies rights for third parties and provides clean demarcation across types of relationships. 